https:// doi.org/10.18485/iipe_cpti.2020.ch3

\title{
BEZBEDNOST U DOBA PANDEMIJA
}

\author{
Vanja ROKVIĆ ${ }^{1}$
}

Apstrakt: Period od pojave prve pandemije, pandemije kuge u VI veku, pa do pandemije COVID-19 u XXI veku, obilovao je pojavom velikog broja zaraznih bolesti koje su imale značajan uticaj na državu i društvo, pa i međunarodnu zajednicu u celini. Pored velike stope morbiditeta i mortaliteta, kroz istoriju su zarazne bolesti ostavljale nesagledive posledice i na ekonomiju, upravljanje državom, snage bezbednosti, vođenje ratova i ravnotežu snaga u međunarodnim odnosima. Korišćenjem originalnih i preglednih naučnih radova, baze podataka Lokacije i događaji u vezi sa oružanim sukobima: COVID19 - praćenje nereda, Matrice za praćenje raseljavanja Međunarodne organizacije za migracije, izveštaja i analiza zvaničnih institucija, nevladinih organizacija i medijskih članka, u ovom preglednom radu analizirani su i prikazani neki od dostupnih podataka o uticajima i posledicama pandemija kako na nacionalnu, tako i međunarodnu bezbednost, sa posebnim osvrtom na pandemiju COVID19. Autorka dolazi do zaključka da, iako su pandemije tokom istorije čovečanstva ostavile mnogobrojne posledice po zdravlje stanovništva, ekonomiju, sistem uređenja vlasti i ravnotežu snaga - nespremnost i globalni haos koji je nastupio nakon pandemije COVID-19, pokazali su da savremeno društvo, kada su u pitanju zarazne bolesti i njihov odnos sa bezbednošću, ima kratkotrajno kolektivno pamćenje.

Ključne reči: pandemija, nacionalna bezbednost, međunarodna bezbednost, COVID-19.

\section{Uvod}

Istorija čovečanstva prožeta je pojavama pandemija zaraznih bolesti koje su imale veliki uticaj na bezbednost, politiku, društvo i ekonomiju. Prve i smrtonosne pandemije kuge, Justinijanova kuga u VI veku i tzv. ,"crna smrt” u XIV veku, kao i smrtonosna pandemija španskog gripa $u$ XX veku,

\footnotetext{
${ }^{1}$ Autorka je vanredni profesor na Fakultetu bezbednosti, Beograd, e-mail: vanjarokvic@fb.bg.ac.rs
} 
značajno su uticale na ravnotežu snaga i ekonomski balans moći, krah određenih oblika vladavine, pa i sam ishod Prvog svetskog rata. Međutim, razmatranje zaraznih bolesti i zdravlja u kontekstu bezbednosti, započinje tek krajem 90-ih godina XX veka, kada se pažnja sa tradicionalnih (vojnih) pretnji bezbednosti pomera na netradicionalne pretnje bezbednosti. Zbog posledica po zdravlje ljudi i velikih ekonomskih gubitaka, HIV/AIDS bila je prva bolest (virus) koju je Savet bezbednosti 2000. godine proglasio netradicionalnom pretnjom bezbednosti i miru. ${ }^{2}$ Iako su period nakon 2000. godine obeležile mnoge druge epidemije i pandemije zaraznih bolesti (prema podacima Svetske zdravstvene organizacije samo u periodu između 2011. godine i 2018. godine, zabeleženo je 1.483 epidemije u 172 države) ${ }^{3}$, a samo neke od njih smatrane su pretnjama kako nacionalnoj, tako i međunarodnoj bezbednosti (SARS, H5N1, H1N1, ebola). Prema Endrjuu Prajs-Smitu (Andrew Price-Smith), pitanje da li će se neki patogen smatrati pretnjom po bezbednost zavisi od nekoliko kriterijuma: mortaliteta, prenosivosti, straha i ekonomskih gubitaka. ${ }^{4}$ Analizom navedenih kriterijuma moglo bi se pak zaključiti da je najdominantniji onaj koji se odnosi na ekonomske gubitke. Tako su procenjeni ekonomski gubici zbog prve pandemije u XXI veku, pandemije H1N1 2009. godine, iznosili između 45 i 55 milijardi dolara, a procenjeni gubici usled epidemije ebole u periodu između 2014. godine i 2016. godine 53 milijarde dolara. Prema procenama Međunarodnog monetarnog fonda, globalna ekonomija zbog pandemije COVID-19 može opasti za oko 3\%, zbog čega bi se svet suočio sa krizom težom od svetske ekonomske krize iz 2008. godine. Ujedno, zbog nespremnosti međunarodne zajednice na pojavu novog virusa, više od 200 država i teritorija uvelo je razne restriktivne mere, poput izolacije, karantina, vanrednog stanja,

${ }^{2}$ Prema podacima Svetske zdravstvene organizacije od pojave HIV-a do 2020. godine umrlo je 32 miliona ljudi. Afrika, kao najpogođeniji region u kojem je samo 2018. godine registrovano 1,1 milion novo-inficiranih, suočava se umanjenjem ekonomskog rasta za 2-4\% na godišnjem nivou. Videti: "HIV/AIDS Global Trends and Data", WHO, https://www.who.int/gho/hiv/en/; 14/05/2020; Simon Dixon, Scott McDonald and Jennifer Roberts, "The Impact of HIV and AIDS on Africa's Economy", BMJ, Vol. 324, January 2002, p. 233.

3 "A World at Risk: annual report on global preparedness for health emergencies", Global Preparedness Monitoring Board, World Health Organization, Geneva, 2019, p. 12.

${ }^{4}$ Andrew T. Price-Smith, Contagion and Chaos Disease, Ecology, and National Security in the Era of Globalization, The MIT Press, Cambridge, Massachusetts London, 2009, p. 4. 
policijskog časa i zatvaranja granica. Nedostatak medicinske opreme naveo je države da stupe u tzv. „rat nabavkama/licitacijama”, a mnoge od njih su usvojile legislative kojima se privremeno zabranjuje izvoz određene medicinske opreme. Preduzimanje restriktivnih mera dovelo je u pitanje vladavinu prava i poštovanje ljudskih i manjinskih prava i stavilo "demokratiju u karantin". Optužbe da je Kina kriva za pandemiju pokrenule su talas mržnje i ksenofobije, a kineska "diplomatija maskama” političke podele u pojedinim državama i regionima.

Iako pojedini autori smatraju da lekcije o posledicama koje su tokom istorije zarazne bolesti imale po društvo, ekonomiju i politiku, mogu doprineti našem razumevanju uticaja i posledica zaraza $u$ savremenom društvu, ${ }^{5}$ suočavanje, kao i odgovor država i međunarodne zajednice na COVID-19, dovodi u pitanje navedenu tvrdnju. Stoga opravdano možemo postaviti pitanje - da li smo naučili lekcije iz prošlosti ili pak imamo kratkotrajno kolektivno pamćenje?

\section{Istorijski i teorijski konstrukt pandemija i bezbednosti}

Zarazne bolesti smatraju se jednim od ,najstarijih i najgorih neprijatelja čovečanstva", ${ }^{6}$ a ako ih posmatramo kao novu pretnju bezbednosti, političkoj i ekonomskoj stabilnosti to je zbog toga što, kako navodi PrajsSmit, „naša vrsta u velikoj meri pokazuje tendenciju kratkotrajnog kolektivnog pamćenja". 7 Prema pisanju Janžong Huanga (Yanzhong Huang), zarazne bolesti su imale mnogo značajniji uticaj na svetsku istoriju nego što bi većina ljudi mogla i da zamisli, ${ }^{8}$ dovodeći do značajnih destabilizacija društava i politike. ${ }^{9}$ Pa tako Džared Dajmond (Jared Diamond) navodi da „pobednici proteklih ratova nisu uvek bile vojske s najboljim generalima i

${ }^{5}$ Ibid., p. 35.

${ }^{6}$ Andrew T. Price-Smith, The Health of Nations Infectious Disease, Environmental Change, and Their Effects on National Security and Development, The MIT Press, Cambridge, Massachusetts London, 2002, p. 3.

${ }^{7}$ Ibid.

${ }^{8}$ Yanzhong Huang, "Pandemics and security", in: Simon Rushton and Jeremy Youde (eds), Routledge Handbook of Global Health Security, Routledge, London and New York, 2015, p. 83.

${ }^{9}$ Andrew T. Price-Smith, Contagion and Chaos Disease, Ecology, and National Security in the Era of Globalization, op. cit., p. 35. 
oružjem, već su često to bile one vojske koje su nosile najgore klice koje se mogu preneti neprijateljima." 10

Tokom istorije pandemije su uticale na „narušavanje ravnoteže snaga i promene međunarodnog i strateškog pejzaža". ${ }^{11}$ Kao primer može se navesti prva pandemija, Justinijanova kuga u VI veku, koja se smatra jednom od prvih negativnih posledica rane faze "globalizacije", budući da se trgovinom i migracijama "putem svile” raširila iz Centralne Azije u Evropu i Istočnu Aziju. Kuga je oslabila Vizantijsko carstvo, onemogućila ponovno ujedinjenje teritorija Rimskog carstva i pomerila regionalni balans ekonomske moći u korist-područja koja nisu bila pogođena kugom. Prema pisanju Prajs-Smita, kuga je delovala kao „stresor ili rastvarač mašinerije carstva” dovodeći do „erozije društvene i državne kohezije, prosperiteta i moći." ${ }^{12}$ Slabljenje Vizantijskog carstva omogućilo je kretanje nomadskih arapskih plemena kroz slabo naseljena područja, stvarajući na taj način uslove za brzo širenje islama. ${ }^{13}$ Pored navedenog, Justinijanova kuga imala je veliki uticaj na demografiju, ali je, kako navodi Džo Hajs (Jo N. Hays), tačan broj preminulih veoma spekulativan. ${ }^{14}$

Potom je u srednjem veku Evropu pogodila tzv. "crna smrt” koja je imala dalekosežne posledice po bezbednost, ekonomsku, socijalnu i političku stabilnost. Procenjuje se da je od posledica ove kuge umrlo između 30\% i 60\% stanovništva Evrope. ${ }^{15}$ U svom radu "Zaraza i haos" Prajs-Smit piše da je kuga "generisala moralnu, socio-političku i ekonomsku dezintegraciju" ${ }^{16}$ Kuga je uticala na moć Mamelučkog sultanata, oslabila

${ }^{10}$ Jared M. Diamond, Guns, Germs, and Steel: The Fates of Human Societies, WW Norton \& Company, New York,1999, p. 197.

${ }^{11}$ Yanzhong Huang, "Pandemics and security", in: Simon Rushton and Jeremy Youde (eds), Routledge Handbook of Global Health Security, op. cit., p. 83.

${ }^{12}$ Andrew T. Price-Smith, Contagion and Chaos Disease, Ecology, and National Security in the Era of Globalization, op. cit., p. 38.

${ }^{13}$ Damir Huremović, "Brief History of Pandemics (Pandemics Throughout History)", Psychiatry of Pandemics: A Mental Health Response to Infection Outbreak 7-35,16 May 2019, p. 14, 16 May 2019, doi:10.1007/978-3-030-15346-5_2.

${ }^{14}$ Jo N. Hays, Epidemics and Pandemics. Their Impacts on Human History, ABC-CLIO, Inc., Santa Barbara, 2005, p. 23.

${ }^{15}$ Jo N. Hays, The Burdens of Disease Epidemics and Human Response in Western History, Rutgers University Press, New Brunswick, New Jersey and London, 2009, p. 37.

${ }^{16}$ Andrew T. Price-Smith, Contagion and Chaos Disease, Ecology, and National Security in the Era of Globalization, op. cit., p. 40. 
vojsku i, prema pojedinim autorima, doprinela otomanskom osvajanju Egipta. ${ }^{17}$ Ujedno, ova zaraza dovela je do destabilizacije i delegitimizacije Rimokatoličke crkve, promene ekonomskog balansa moći ka regionima koji nisu bili zaraženi, i na kraju je uticala i na krah samog feudalnog sistema. Kako navodi Džejson Mur (Jason Moor), „,crna smrt” je dramatično pomerila odnos snaga u korist kmetova i ",potpisala smrtnu presudu feudalizmu”. ${ }^{18}$ Pojava zaraze manifestovala se i ksenofobijom, odnosno pogromom Jevreja u Evropi koji su bili optuživani da hrišćanima truju bunare, ali je i dovela do stigmatizacije i diskriminacije ostalih društvenih grupa. ${ }^{19} \mathrm{U}$ ovom periodu ujedno je došlo i do razvoja prvih struktura posvećenih upravljanju javnim zdravljem. Tako praksa karantina (quarantenaria - od italijanske reči quaranta giorni - četrdeset dana) potiče iz Venecije, kada je 20. marta 1348. godine uveden karantin za brodove. Mere karantina radi kontrolisanja protoka zaražene robe i izolacije bolesnih razvio je Bernabo Viskonti (Viscount Bernabo of Reggio), i prvi put su uspostavljene 1374. godine $\mathrm{u}$ gradovima Mantovi (Lombardija) i u Dubrovniku (mediteranskoj luci oblasti Raguzia).$^{20}$ Odluka Viskontija bila je da se svaka osoba obolela od kuge „odvede van grada na poljane, da bi se oporavila ili umrla”. ${ }^{21}$

Tokom pandemije kuge posao oružanih snaga bio je da obezbeđuju red u gradovima i regionima, odnosno oružane snage igrale su ulogu tzv. sanitarnog kordona (cordon sanitaire). U Firenci je čak zahtevano da ljudi nose ,zdravstvene pasoše", kojima bi dokazali da nemaju kugu. ${ }^{22}$ Tokom 1604. godine u Engleskoj je svako, pod sumnjom da ima kugu a nalazi se na ulici, mogao biti obešen. ${ }^{23}$ Španija je takođe 1679 . godine primenila slične modele, koristeći oružane snage za kontrolu kretanja između zaraženih i nezaraženih područja. Habzburški režim je 1739. godine uspostavio „zonu kontrole kuge", u kojoj su oružane snage imale dozvolu da pucaju na

\footnotetext{
${ }^{17}$ Ibid., p. 41

${ }^{18}$ Jason W Moor, "THE CRISIS OF FEUDALISM: An Environmental History", Organization E Environment, Vol. 15, No. 3, September 2002, p. 306.

${ }^{19}$ Ibid., p. 42.

${ }^{20}$ Ibid., pp. 43-45.

${ }^{21}$ Philip A. Mackowiak, Paul S. Sehdev, "The Origin of Quarantine”, Clinical Infectious Diseases, Vol. 35, No. 91, November 2002, p. 1072.

${ }^{22}$ Andrew T. Price-Smith, Contagion and Chaos Disease, Ecology, and National Security in the Era of Globalization, op. cit., pp. 43-44.

${ }^{23}$ Ibid., p. 44.
} 
putnike. Ovi tzv. sanitarni kordoni bili su raspoređeni na teritoriji Hrvatske, Transilvanije i regionima južno od Dunava. ${ }^{24}$

U razmatranju uticaja pandemija na bezbednost, gotovo nezaobilazna tema je španski grip ili „purpurna smrt” koja je pogodila svet u završnici Prvog svetskog rata. Procenjuje se da je 25\% svetske populacije bilo zaraženo, odnosno, da je od posledica ove bolesti preminulo oko 50 miliona ljudi (samo u Indiji između 18 i 20 miliona). ${ }^{25}$ Španska groznica imala je veliki uticaj na oružane snage, budući da je rat doprineo širenju infekcije. Pored visoke stope morbiditeta i mortaliteta, zaraza je uticala i na moral, koheziju i efikasnost oružanih snaga kao i na sam ishod Prvog svetskog rata. ${ }^{26}$ Deo ratne propagande bilo je optuživanje neprijatelja za širenje zaraze, pa je tako bilo rasprostranjeno uverenje da je pandemija nastala u Kini, jer su Nemci za pandemiju optuživali kineske radnike koje su savezničke sile unajmile za rad. ${ }^{27}$ Ujedno, kako navodi Prajs-Smit, zaraza je imala ",sklerotičan uticaj na upravljanje ${ }^{\prime 28} \mathrm{u}$ pogođenim državama, budući da je prevazilazila kapacitete država da odgovore na zarazu i da se na efikasan način suoče sa njenim posledicama. Mnoge države preduzele se određene mere u cilju sprečavanja širenja zaraze, poput zabrane javnih okupljanja, zatvaranja škola, verskih objekata i sl. Takođe, kako navodi Eudžinija Tonjoti (Eugenia Tognotti), tadašnji mediji (novine) zauzeli su suprotnu stranu u odnosu na preduzete mere i time doprinele širenju panike. Zbog toga su vlasti u Italiji primorale najuticanije novine Corriere della Sera, da prestanu da objavljuju broj preminulih u Milanu (150-180 smrtnih slučajeva po danu), zbog stvaranja velike anksioznosti među građanima. ${ }^{29}$ Smatra se da bi u savremenom svetu, u slučaju pojave zaraze slične virulentnosti kao španski grip, za manje od 36 sati moglo umreti od 50 do 80 miliona ljudi. Pandemija ovakvih razmera

${ }^{24} \mathrm{Ibid}$.

${ }^{25} \mathrm{Jo}$ N. Hays, Epidemics and Pandemics. Their Impacts on Human History, op. cit., p. 385.

${ }^{26}$ Andrew T. Price-Smith, Contagion and Chaos Disease, Ecology, and National Security in the Era of Globalization, op. cit., p. 78.

${ }^{27}$ Jo N. Hays, Epidemics and Pandemics. Their Impacts on Human History, op. cit., p. 390.

${ }^{28}$ Andrew T. Price-Smith, Contagion and Chaos Disease, Ecology, and National Security in the Era of Globalization, op. cit., p. 78.

${ }^{29}$ Eugenia Tognotti, "Lessons from the history of quarantine, from plague to influenza A", Emerging Infectious Diseases, Vol. 19, No. 2, February 2013, p. 257. 
izazvala bi opštu paniku, destabilizovala nacionalnu bezbednost i ozbiljno ugrozila globalnu ekonomiju. ${ }^{30}$

Međutim, i pored navedenih slučajeva iz istorije (kojih je bilo mnogo više nego što je $\mathrm{u}$ ovom delu rada prikazano), ${ }^{31}$ prvo istraživanje veze između javnog zdravlja i bezbednosti uspostavio je Denis Piraž (Dennis Pirages) 1995. godine. On je u svom radu naveo da širenju bolesti doprinose demografski faktori (poput rasta populacije, urbanizacije, ekonomskog pada, migracija, izbeglica); potom promene $u$ ljudskom ponašanju; promene $u$ životnoj sredini i tehnološke inovacije (transport, distribucija hrane, proizvodnja antibiotika i drugo). Zalažući se za koncept "mikrobezbednosti” i posmatranje bezbednosti ne samo sa stanovišta tradicionalnih (vojnih), već i netradicionalnih pretnji, Piraž predlaže da prvi korak u rešavanju problema bude razumevanje veze između ljudskih aktivnosti i opasnosti od budućih zaraza, ali i da se o zarazama razmišlja sa vojnog stanovišta, odnosno stanovišta nacionalne bezbednosti. ${ }^{32}$ Kolin Makins (Colin McInnes) navodi da se za „početak tretiranja zdravlja kao bezbednosnog pitanja” uzima period kraja 90-ih godina XX veka, kada se pažnja sa vojnih pretnji bezbednosti pomera na "difuznije opasnosti”. ${ }^{33}$ Ovome je, svakako, doprinelo i usvajanje prve rezolucije o netradicionalnim pretnjama bezbednosti, odnosno usvajanje Rezolucije 1308 (2000), kojom je po prvi put u istoriji jedna bolest (HIV/AIDS) proglašena pretnjom po međunarodni mir i bezbednost. Rezolucijom je naglašeno da pandemija HIV/AIDS ima ,razarajući uticaj na sve sektore i nivoe društva" i da ",predstavlja rizik po stabilnost i bezbednost" ${ }^{34}$ Od ovog perioda, posmatranje zdravlja "kroz prizmu bezbednosti postaje integralni deo upravljanja javnim zdravljem u XXI veku", ${ }^{35}$ a Dejvid Fidler (David P.

30 "A World at Risk: annual report on global preparedness for health emergencies", Global Preparedness Monitoring Board, World Health Organization, Geneva, 2019, p. 15.

${ }^{31}$ Videti: Jo N. Hays, Epidemics and Pandemics. Their Impacts on Human History, ABCCLIO, Inc., Santa Barbara, 2005.

${ }^{32}$ Dennis Pirages, "Microsecurity: Disease organisms and human well-being", Washington Quarterly Vol. 18, Issue 4, 1995, pp. 5-12.

${ }^{33}$ Kolin Makins, "Zdravlje”, u: Pol Vilijams (ur), Uvod u studije bezbednosti, Fakultet bezbednosti i JP Službeni glasnik, Beograd, 2012, str. 361.

34 "Resolution 1308 (2000)", Security Council of the United Nations, 17 July 2000.

${ }^{35}$ Collen O'Manique and Piter Fouire, "Security and health in the twenty-first century", in: Myriam Dunn Cavelty and Victor Mauer (eds), Routledge Handbook of Security Studies, Routledge, London and New York, 2010, p. 243. 
Fidler) čak govori o „političkoj revoluciji” u odnosima između zdravlja, spoljne politike i međunarodnih odnosa. ${ }^{36}$ Ovome su pored posledica koje decenijama ostavlja pandemija HIV/AIDS, doprinele i posledice epidemija i pandemija u XXI veku, kao što su SARS (2003), H5N1 (2004), H1N1 (2009), ebola (2014) $)^{37} \mathrm{i}$ druge. U literaturi se navodi da su navedene bolesti smatrane pretnjom po bezbednost ne zbog toga što su usmrtile veliki broj ljudi (od posledica SARS-a preminule su 774 osobe), već zbog toga što se veliki broj ljudi plašio da hoće. ${ }^{38}$ Krajst Enmark (Christ Enmark) navodi da su u slučaju SARS-a velika neizvesnost i strah proistekli zbog nedovoljnih medicinskih podataka o bolesti, kao i zbog velikog medijskog publiciteta koji je potpirivao neizvesnost i dovodio do prekomernih reakcija. ${ }^{39}$ Zapravo, veći broj patogena u kontekstu mortaliteta i morbiditeta samo je potencijalno destruktivan, ali pojava novih patogena ",nužno uključuje veliki stepen neizvesnosti”, što utiče na (ne)efikasnost kolektivnog odgovora na iste..$^{40}$ Pojava SARS-a, ali i drugih zaraznih bolesti, dovele su do velikih ekonomskih posledica i ukazale na nespremnost i nedovoljne kapacitete država da na njih odgovore. Zbog navedenog, kao i zbog širenja straha i panike, uvođenja restriktivnih mera, kao najznačajnije naučene lekcije prethodnih zaraza (prevashodno SARS-a) Enmark navodi sledeće: 1 . vlade koje žele da spreče širenje zarazne bolesti za koje se smatra da predstavljaju pretnju bezbednosti moraju da uspostave ravnotežu između očuvanja javnog zdravlja i poštovanja ljudskih prava; 2. medicinski radnici moraju biti dobro pripremljeni i opremljeni; i 3. pravovremena komunikacija, kako na nacionalnom tako i na međunarodnom nivou od suštinske je važnosti za sprečavanje širenja zaraze. ${ }^{41}$ Ali se s pravom možemo zapitati - da li smo zaista nešto i naučili?

${ }^{36}$ David P. Fidler, "Health as Foreign Policy: Between Principle and Power", Whitehead Journal of Diplomacy and International Relations, Vol. 6, No. 2, 2005, pp. 179-194.

${ }^{37}$ Nakon usvajanja Rezolucije 1308, Savet bezbednosti UN usvojio je Rezoluciju 2177, 2014. godine kojom se Ebola proglašava pretnjom po međunarodni mir i bezbednost.

${ }^{38}$ Christ Enmark, Disease and Security. Natural plagues and biological weapons in East Asia, op. cit., p. 32.

${ }^{39}$ Ibid.

${ }^{40}$ Kristian, Bjørkdahl, Benedicte Carlsen, (eds), Pandemics, Publics, and Politics. Palgrave, Singapore, 2019, p. 1.

${ }^{41}$ Christ Enmark, Disease and Security. Natural plagues and biological weapons in East Asia, op. cit., p. 33. 


\section{Pandemije i nacionalna bezbednost}

Mnogi autori iz oblasti sekuritizacije zdravlja u svojim istraživanjima o uticaju bolesti na bezbednost polaze od rada Ričarda Ulmana (Richard Ullman), ${ }^{42}$ koji smatra da definisanje nacionalne bezbednosti samo sa vojnog stanovišta stvara lažnu sliku stvarnosti, i dovodi do toga da se države fokusiraju na vojne pretnje i zanemaruju mnoge druge pretnje koje mogu biti čak i opasnije. Prema Ulmanovoj definiciji, pretnje nacionalnoj bezbednosti su radnja ili niz događaja koji: (1) ,prete da drastično i u relativno kratkom vremenskom periodu degradiraju kvalitet života građana, ili (2) prete da drastično suze izbor praktičnih politika koje su dostupne vladama ili privatnim, nevladinim subjektima u okviru države" ${ }^{.} 3$ Polazeći od Ulmanove definicije i kriterijuma da li određeni patogen predstavlja pretnju bezbednosti (mortalitet, prenosivost, strah i ekonomski gubici), Prajs-Smit je razvio model delovanja zaraznih bolesti na nacionalnu bezbednost (prikaz br. 1).

Prikaz 1: Model delovanja zaraznih bolesti na nacionalnu bezbednost prema Prajs-Smitu ${ }^{44}$

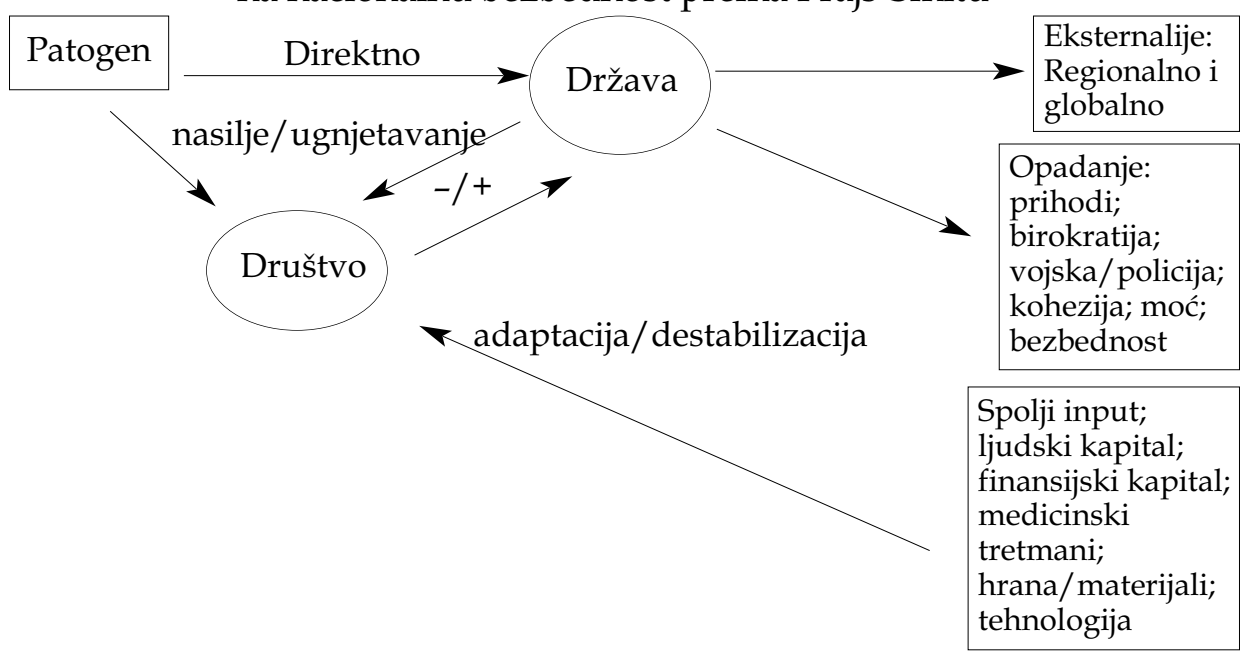

${ }^{42}$ Andrew T. Price-Smith, Yanzhong Huang, Christ Enmark i drugi.

${ }^{43}$ Citirano prema: Andrew T. Price-Smith, Contagion and Chaos Disease, Ecology, and National Security in the Era of Globalization, op. cit., p. 78.

${ }^{44}$ Ibid., p. 17. 
U navedenom modelu patogen predstavlja nezavisnu varijablu, budući da su etiologija, smrtnost, kao i vektori transmisije novonastalog patogena na početku nejasni, te on stoga može stvoriti ogromnu neizvesnost, anksioznost i strah kod pogođene/izložene populacije. Virulentni i destruktivni patogen može direktno uticati na državu, ili se njegovo dejstvo na državu može reflektovati preko uticaja na društvo (intervenišuća varijabla). Prajs-Smit navodi da zaraza može uticati na društvo u mnogim sferama, poput demografije, ekonomije, politike i psihologije. U domenu demografije, patogeni dovode do morbiditeta i mortaliteta populacije, ali mogu uticati i na fertilitet, kao i podstaći migracije iz pogođenih regiona. ${ }^{45}$ Zapravo, zarazne bolesti čine najveći udeo morbiditeta i mortaliteta u svetu, „prevazilazeći rat kao najveću pretnju ljudskom životu i prosperitetu” ${ }^{46}$ Radi ilustracije, Prajs-Smit navodi podatke da je 1990. godine zabeleženo $49.971,000$ smrtnih slučajeva, od koji je $34,4 \%$ posledica zaraznih bolesti, a svega $0,64 \%$ posledica ratnih dešavanja. ${ }^{47}$ Prema podacima Svetske zdravstvene organizacije samo od sezonskog gripa na godišnjem nivou umire i do 650.000 ljudi, $^{48}$ a od pojave HIV-a do 2020. godine umrlo je 32 miliona ljudi. ${ }^{49} \mathrm{U}$ domenu ekonomije, patogeni utiču na produktivnost radnika i mogu nametnuti niz direktnih i indirektnih troškova kompanijama i makroekonomiji. Zaraza može destabilizovati tržište kroz prekid snabdevanja, umanjenje domaće štednje, priliv stranih investicija i drugo. Uticaj na ekonomiju može se odraziti i kroz smanjenje trgovine (uvoza i izvoza), prihoda od poreza, smanjenje kapaciteta pružanja javnih usluga, ugrožavajući samim tim i legitimitet države, ali i bezbednost. ${ }^{50} \mathrm{Kao}$ primer možemo navesti zabranu EU na izvoz govedine iz Velike Britanije,

\footnotetext{
${ }^{45}$ Ibid., p.78.

${ }^{46}$ Andrew T. Price-Smith, The Health of Nations. Infectious Disease, Environmental Change, and Their Effects on National Security and Development, op. cit., 2.

${ }^{47}$ Ibid.

48 "Up to 650000 people die of respiratory diseases linked to seasonal flu each year", WHO, 14 December 2017, https:/ / www.who.int/news-room/detail/14-12-2017-upto-650-000-people-die-of-respiratory-diseases-linked-to-seasonal-flu-each-year, $17 / 05 / 2020$.

49 „HIV/AIDS Global Trends and Data“, WHO, https://www.who.int/gho/hiv/en/; 14/05/2020.

${ }^{50}$ Andrew T. Price-Smith, Contagion and Chaos Disease, Ecology, and National Security in the Era of Globalization, op. cit., p. 20.
} 
koja je trajala je deset godina, zbog bolesti „ludih krava” (od 1996. godine do 2006. godine). Pre marta 1996. godine ovaj sektor činio je 0,5\% BDP Velike Britanije, ${ }^{51}$ a samo u prvoj godini epidemije ukupni ekonomski gubici za Britaniju iznosili su oko 980 miliona dolara. ${ }^{52}$ Ujedno, procenjeni gubici za Britaniju tokom pandemije H1N1 u periodu od juna 2009. do marta 2011. godine iznosili su 45,3 miliona britanskih funti..$^{53}$ Tokom epidemije ebole $u$ periodu od 2013. godine do 2014. godine pad BDP u Liberiji iznosio je $8 \%,{ }^{54}$ dok su tokom 2015. godine direktni gubici za Gvineju, Liberiju i Sijera Leone procenjeni na 2,2 milijarde dolara. ${ }^{55}$ Kada je u pitanju pandemija COVID19 možemo navesti dokument Evropskog parlamenta $\mathrm{u}$ kome su predviđeni mogući scenariji za nekoliko država. Tako, npr. Centralna banka Portugalije razmatra dva moguća scenarija - osnovni i negativni. U slučaju osnovnog scenarija BDP Portugalije tokom 2020. smanjiće se za 3,7\%, dok će prema negativnom scenariju portugalska ekonomija ući će u još veću recesiju i BDP će pasti za 5,7\% tokom 2020. godine. Holandski Biro za analizu ekonomske politike napravio je četiri moguća scenarija koji obuhvataju projekcije za 2020. i 2021. godinu. Svi scenariji ukazuju na recesiju 2020. godine, i predviđaju pad do 7,7\%. ${ }^{56}$ Prema izveštaju Organizacije za ekonomsku saradnju i razvoj (OECD) ekonomija u Srbiji ući će u recesiju 2020. godine, a procenjeni gubici u infrastrukturi i transportu

51 "Economic Impact and International Trade", BSE Inquiry Report, Vol. 10, 1996, http://www.fao.org/livestock/AGAP/FRG/Feedsafety/PDFs/philips10.pdf, 15/04/2020.

${ }^{52}$ Colin A. Carter, Jascqueline Huie, "Market Effects of Searching for Mad Cows", Giannini Foundation of Agriculture and Economics, Vol. 8, No. 2, Sep/Oct 2004, p. 6.

${ }^{53}$ Angelos Delivorias, Nicole Scholz, "Economic impact of epidemics and pandemics", European Parliamentary Research, February 2020, p. 2. https://www.europarl. europa.eu/RegData/etudes/BRIE/2020/646195/EPRS_BRI(2020)646195_EN.pdf, 23/05/2020.

${ }^{54}$ David E. Bloom, Daniel Cadarette and J.P. Sevilla, "Epidemics and Econimics", Finance E Development, Vol.55, No. 2, June, 2018, p. 46.

55 "2014-2015 West Africa Ebola Crisis: Impact Update", World Bank Group, 10 May 2016, p. 2. http:/ / pubdocs.worldbank.org/en/297531463677588074/Ebola-Economic -Impact-and-Lessons-Paper-short-version.pdf, 22/05/2020.

${ }^{56}$ Saverio Lenzi, Andrea Di Filippo, Javier Vega Bordell, "The economy and coronavirus: Weekly Picks", European Parliament, 06 April 2020, https:/ / www.euro parl.europa.eu/RegData/etudes/BRIE/2020/645717/IPOL_BRI\%282020\%29645717 _EN.pdf, 23/05/2020. 
u martu 2020. godine iznosili su više od 110 miliona evra, a gubici u turizmu u periodu između marta i aprila 2020. godine 2,7 miliona evra. ${ }^{57}$

U domenu psihologije, zaraza može izazvati niz negativnih posledica, kao što su povećana neizvesnost, pogrešna percepcija, stigmatizacija, diskriminacija, emotivni problemi i slično. ${ }^{58}$ Huang navodi, da zbog straha i neizvesnosti zarazne bolesti često deluju kao katalizator društvene nestabilnosti. ${ }^{59}$ Iako diskriminacija i stigmatizacija određenih grupa u vreme zaraznih bolesti nije nov fenomen, on je za vreme pandemije COVID-19 postao globalan. ${ }^{60}$ Prema rečima generalnog sekretara UN Antonija Gutereša (António Guterres), pandemija je oslobodila „cunami mržnje i ksenofobije, žrtvovanja i zastrašivanja" ${ }^{61}$ Podaci Human Right Watch-a pokazuju da su u mnogim zemljama zabeleženi slučajevi diskriminacije i nasilja nad Azijatima. ${ }^{2}$ Prema pisanju Adama Berka (Adam Burke) u Pakistanu je manjinska muslimanska grupa šiita optužena da je donela virus iz Irana, a slični slučajevi zabeleženi su i u drugim državama. ${ }^{63}$ Pojedine države našle su se u fokusu zbog nejednakog tretmana i pružanja pomoći svim društvenim grupama. Tako je npr. u Bangladešu vlada ukinula pristup internetu za oko 900.000 pripadnika Rohinja, grupe u izbegličkom kampu

57 “The Covid-19 Crisis in Serbia”, OECD, 25 May 2020, https:/ / www.oecd.org/ southeast-europe/COVID-19-Crisis-in-Serbia.pdf, 30/05/2020.

${ }^{58}$ Andrew T. Price-Smith, Contagion and Chaos Disease, Ecology, and National Security in the Era of Globalization, op. cit.

${ }^{59}$ Yanzhong Huang, "Pandemics and security", in: Simon Rushton and Jeremy Youde (eds), Routledge Handbook of Global Health Security, op. cit., p. 86.

60 "COVID-19-related discrimination and stigma: a global phenomenon?", UNESCO, 25 May 2020, https://en.unesco.org/news/covid-19-related-discrimination-andstigma-global-phenomenon, 29/05/2020.

61 "Secreary-General Denounces 'Tsunami' of Xenophobia Unleashed amid COVID-19, Calling for All-Out Effort against Hate Speech", United Nations, Meetings Coverage and Press Releases, 08 May 2020, https://www.un.org/press/en/2020/sgsm200 76.doc.htm, 27/05/2020.

${ }^{62}$ Beyza Binnur Donmez, "Report says virus fuels anti-Asian racism, xenophobia Governments should take urgent steps to counter intolerance, says Human Rights Watch amid coronavirus pandemic", Andaolu Agency, 13 May 2020, https://www.aa.com.tr/en/latest-on-coronavirus-outbreak/report-says-virus-fuelsanti-asian-racism-xenophobia/1839509, 30/05/2020.

${ }^{63}$ Adam Burke, "Peace and the pandemic: the impact of COVID-19 on conflict in Asia", Devpolicy Blog, 14 April 2020, https:/ / devpolicy.org/peace-and-the-pandemic-theimpact-of-covid-19-on-conflict-in-asia-20200414/, 26/05/2020. 
Cox's Bazar, čime je smanjena dostupnost informacija o virusu, a stigmatizacija potencijalno obolelih dovela je do toga da se eventualni simptomi bolesti ne prijavljuju i da se ne traži adekvatan medicinski tretman. ${ }^{64}$ Nažalost, i Srbija se našla među onim državama u kojima je izostala podrška određenim grupama. Zbog neadekvatnog tretmana i izostanka podrške najosetljivim grupama, pre svega romskoj populaciji koja živi u neformalnim naseljima, Evropski sud za ljudska prava pokrenuo je postupak protiv Srbije. ${ }^{65}$

U predstavljenom modelu država čini zavisnu varijablu na koju negativan uticaj patogena može biti indirektan, preko društva, ali i direktan kada zaraza dovodi do slabljenja ili uništenja ljudskih resursa (vojnika, policije, birokrata), kao i slabljenja državnih institucija. U ovakvim situacijama vlast može primeniti određene mere kako bi kontrolisala zarazu, što za posledicu može dovesti do konflikata. Enmark navodi da u slučajevima epidemija i pandemija, kao u slučaju SARS-a 2003. godine, vlada može uvesti mere izolacije i karantina, koje će uticati na ljudska prava (pravo na slobodu kretanja, privatnost i sl.), ali i vladavinu prava. ${ }^{66}$ Zapravo, u mnogim državama uvođenje ovakvih mera doprinelo je diskriminaciji i stigmatizaciji, što je rezultiralo ogorčenjem građana i raznim protestima i nemirima. ${ }^{67}$ Tonjoti smatra da istorijska perspektiva uvođenja mera karantina i izolacije može pomoći u razumevanju do koje mere panika, stigmatizacija i predrasude mogu uticati na napore države da se kontroliše širenje zaraze, što je naročito važno u globalizovanom svetu gde se strah i panika podstaknuti novim medijama šire brže i dalje. ${ }^{68} \mathrm{I}$ opet se postavlja pitanje - da li je lekcija iz prošlosti naučena?

64 Ibid.

65 “European Court Of Human Rights Has Initiated Procedure Against Serbia For Lack Of Support For The Most Vulnerable In The Fight Against Coronavirus", Forum Roma Srbije, 2020, http:/ / www.frs.org.rs/en/european-court-of-human-rights-hasinitiated-procedure-against-serbia-for-lack-of-support-for-the-most-vulnerable-inthe-fight-against-coronavirus/, 27/05/2020.

${ }^{66}$ Christ Enmark, Disease and Security. Natural plagues and biological weapons in East Asia, The Routledge, New York \& London, 2007, p. 7.

${ }^{67}$ Eugenia Tognotti, "Lessons from the history of quarantine, from plague to influenza A", Emerging Infectious Diseases, op. cit., p. 258.

${ }^{68}$ Ibid. 
Naime, dok su u slučaju SARS-a i drugih zaraznih bolesti navedene mere preduzimane samo $u$ određenim državama (u slučaju SARS-a $u$ Kanadi, Kini, Singapuru, Hong Kongu, Tajvanu i Vijetnamu), u slučaju pandemije COVID-19 one su postale planetarne. Do kraja marta 2020. godine više od 100 država u potpunosti ili delimično uvele su restriktivne mere poput izolacije, karantina, vanrednog stanja, policijskog časa i zatvaranja granica. ${ }^{69} \mathrm{U}$ okviru sistema Matrica za praćenje raseljavanja (Displacement Tracking Matrix) Međunarodne organizacije za migracije, razvijena je baza Monitoring ograničenja putovanja usled pandemije COVID-19 (COVID-19 Travel Restriction Monitoring). Na dnevnoj bazi vrši se ažuriranje mera ograničenja koje države uvode ili pak ukidaju. Tako je 10. marta 2020. godine zabeleženo 5.430 raznih ograničenja uvedenih u 105 država, dok je 28. maja 2020. godine, taj broj iznosio 63.381 u 220 država i teritorija. ${ }^{70}$ Uvođenje određenih mera u pojedinim državama izazvalo je otpor građana. Prema podacima baze podataka Lokacije $i$ događaji u vezi sa oružanim sukobima: COVID-19 - praćenje nereda (ACLED - Armed Conflict Location and Event Data Project: COVID-19 Disorder Tracker) koja prikuplja podatke o uticaju pandemije na različite vrste nasilja i događaja (političko nasilje, represija, protesti, demonstracije, oružani sukobi i drugo), ${ }^{71}$ u mnogim zemljama došlo je do antivladinih demonstracija zbog odgovora države na pandemiju i preduzete mere. Tako su demonstracije zabeležene $u$ Kambodži, Vijetnamu, Tajlandu, Južnoj Koreji, Hong Kongu, Tajvanu, Hondurasu, Guatemali, Meksiku, El Salvadoru, Panami, Trinidad i Tobagu, Kolumbiji, Venecueli, Argentini, Ekvadoru, Brazilu, Peruu, Boliviji, Bugarskoj, Grčkoj, Rumuniji, Nemačkoj, Ukrajini, Velikoj Britaniji, Mađarskoj, Španiji, Sloveniji i mnogim drugim državama. Razlozi protesta odnosili su se na socio-ekonomske mere, nemogućnost rada, ugrožavanje

${ }^{69}$ Daniel Dunford et al, "Coronavirus: The world in lockdown in maps and charts", BBC News, 7 April 2020, https:/ / www.bbc.com/news/world-52103747, 15/05/2020.

70 "Covid-19 Disease Response", Situation Report 17, IOM, 23-29 May 2020, https://reliefweb.int/sites/reliefweb.int/files/resources/iom_covid-19_sitrep17_2329may2020_final.pdf, 31/05/2020.

${ }^{71} \mathrm{U}$ bazi su prikazani podaci o mestu, vremenu, akterima, vrsti i posledicama političkog nasilja, sa posebnim osvrtom na građanske, lokalne sukobe, nasilje nad civilima, proteste i nerede, kao i podaci o uticaju pandemije na različite vrste nasilja i događaja. Više o ovoj i ostalim bazama u: Ivan Dimitrijević, Ana Paraušić, Katalog baza podataka za istraživanja u oblasti bezbednosti, Fakultet bezbednosti, Beograd, 2017. 
građanskih sloboda, a u velikom broju država protestvovali su i zdravstveni radnici zbog neadekvatne zaštite, nedostatka medicinske opreme i uslova rada. Ujedno, prema podacima iz ove baze, u pojedinim državama došlo je do povećanja državne represije, pa se tako navodi da je vlada u Meksiku usvojila dekret kojim se daju veća ovlašćenja oružanim snagama za delovanje u sferi javne bezbednosti. ${ }^{72}$ U Mađarskoj je usvojen nov zakon kojim su za širenje vesti za koje se smatra da su lažne propisane kazne od nekoliko godina zatvora, ${ }^{73}$ a ove, kao i druge uvedene mere u Mađarskoj, dovele su do preispitivanja demokratskih vrednosti i ukazivanja na to da se pod velom pandemije uvodi ,korona diktatura". ${ }^{74}$ Na Filipinima je, nakon što je predsednik Duterte izjavio da snage bezbednosti mogu slobodno pucati na osobe koje ne poštuju policijski čas, ubijena jedna osoba, dok je u velikom broju država primenjena prekomerna sila od strane snaga bezbednosti u cilju sprovođenja vladinih mera (npr. u Rumuniji nad romskom populacijom). ${ }^{75}$

Slično viđenje uticaja zaraznih bolesti na nacionalnu bezbednost imaju i drugi autori, pa tako Huang navodi da pandemije mogu oslabiti nacionalnu ekonomiju, društvenu stabilnost i političke institucije. ${ }^{76}$ Štaviše, prema Huangu, pandemije se mogu smatrati pretnjom nacionalnoj bezbednosti čak i ako prihvatimo tradicionalno određenje bezbednosti koje se fokusira na upotrebu vojne moći u zaštiti nacionalnih interesa. Naime, pandemije mogu značajno uticati na efektivnost oružanih snaga, kao i na sprovođenje vojnih operacija. ${ }^{77}$ Kao primer možemo navesti epidemiju tifusa 1915. godine u Srbiji. Procenjuje se da je od posledica tifusa umrlo

72 "Increased Demonstration Activity Over Government Response", ACLED: COVID19 Disorder Tracker, 2020 https://acleddata.com/analysis/covid-19-disordertracker/\#1585775314361-2ee40e97-5aec, 28/05/2020.

${ }^{73}$ Ibid.

${ }^{74}$ Jamie Dettmer, "Hungary: The First Dictatorship in the EU?", VOA News, 06 May 2020, https:// www.voanews.com/covid-19-pandemic/hungary-first-dictatorshipeu, $12 / 05 / 2020$.

75 "Increased Demonstration Activity Over Government Response", ACLED: COVID19 Disorder Tracker, 2020 https://acleddata.com/analysis/covid-19-disordertracker/\#1585775314361-2ee40e97-5aec, 28/05/2020.

${ }^{76}$ Yanzhong Huang, "Pandemics and security", in: Simon Rushton and Jeremy Youde (eds), Routledge Handbook of Global Health Security, op. cit., p. 86.

77 Ibid., p. 85. 
35.000 srpskih vojnika. ${ }^{78}$ Veliki uticaj na oružane snage imala je i pandemija španskog gripa. Od posledica ovog gripa umrlo više od 45.000 pripadnika oružanih snaga SAD. ${ }^{79}$ Istraživanje prevalence HIV-a među pripadnicima oružanih snaga u afričkim zemljama, koje je sproveo Nacionalni obaveštajni savet SAD, pokazao je da se ona kreće od 10\% u Eritreji, do $60 \%$ u DR Kongo. ${ }^{80}$ Takođe, pripadnici oružanih snaga mogu doprineti širenju zaraze kao učesnici oružanog sukoba, ${ }^{81}$ ali i u svojstvu pripadnika mirovnih misija čime se otežava održavanje mira i bezbednosti. ${ }^{82}$

Iako se veliki broj istraživanja i radova fokusira na uticaj epidemija i pandemija na nacionalnu bezbednost, činjenica je da, kako navode Denis Piraž i Pol Runci (Paul Runci), virusi i bakterije ne poznaju državne/nacionalne granice: „virusi, bakterije i razne vrste biljaka $i$ životinja, nikada nisu poštovale državne granice. Prelazili su granice sa vetrom, vodom, istraživačima, trgovcima i najamnicima. Većinom su ovakvi prelasci bili bez posledica, ali su zato povremeno čitava društva i ekosistemi bili preoblikovani. Danas pak raste zabrinutost zbog povećanog uticaja globalizacije na potencijalni razvoj $i$ širenje novih $i$ oživljavanje starih bolesti preko sve poroznijih granica". ${ }^{83} \mathrm{U}$ uslovima globalizacije, brzih promena i međuzavisnosti država, kako piše Džejms Rozenau (James Rosenau), ,,razdvajanje nacionalnih i međunarodnih odnosa je problematično", ${ }^{84}$ a pojava zarazne bolesti u jednom delu sveta , je samo

${ }^{78}$ Vanja Rokvic, Zoran Jeftic, Vladimir Ajzenhamer, "Public health in Serbia through the lens of security", IJPH, Vol. 4, No. 9, September 2016, pp. 1136-1145.

${ }^{79}$ Eric Durr, "Worldwide flu outbreak killed 45,000 American Soldiers during World War I", 31 August 2018, U.S. Army, https://www.army.mil/article/210420/ worldwide_flu_outbreak_killed_45000_american_soldiers_during_world_war_i 10/05/2020.

80 "The Global Infectious Disease Threat and Its Implications for the United States", The U.S. National Intelligence Council, 2000, https://www.dni.gov/files/documents/ infectiousdiseases_2000.pdf, 19/05/2020.

${ }^{81}$ Stefan Elbe, "HIV/AIDS and the Changing Landscape of War in Africa." Quarterly Journal: International Security, Vol. 27, No. 2., Fall 2002, pp. 159-177.

${ }^{82}$ Kolin Makins, "Zdravlje”, u: Pol Vilijams (ur), Uvod u studije bezbednosti, Fakultet bezbednosti i JP Službeni glasnik, Beograd, 2012, str. 366.

${ }^{83}$ Dennis Pirages and Paul Runci, "Ecological Interdependence and the Spread of Infectious Disease" in Maryann Cusimano (Ed), Beyond Sovereignty: Issues for a Global Agenda, New York, St. Martin's Press, 2000, p176.

${ }^{84}$ James N. Rosenau, Along the domestic-foreign Frontier. Exploring governance in a turbulent world, Cambridge University Press, New York, 1997, p. 3. 
nekoliko sati udaljena od toga da postane neposredna pretnja bilo gde". ${ }^{85}$ Prema Prajs-Smitu, destabilizacija jedne države uzrokovana patogenom može proizvesti negativne eksternalije koje će uticati na druge države $u$ međunarodnom sistemu, ekonomsku destabilizaciju, poremećaje u protoku robe i ljudi, ali i političke nestabilnosti. U određenim situacijama zaraza može podstaći politički nesklad, narušiti efikasno funkcionisanje međunarodnih organizacija i stvoriti probleme $u$ saradnji između nacionalnih država i drugih subjekata $\mathrm{u}$ domenu upravljanja javnim zdravljem. ${ }^{86}$

\section{Pandemije i međunarodna bezbednost}

Ukoliko pođemo od stava da se u kontekstu pretnji međunarodnoj bezbednosti najbolje mogu uočiti one „makropojave značajne za ceo svet”, 87 mogli bismo reći da je jedna od najznačajnih upravo ona koja pokreće svet - ekonomija. Odnosno, da se u kontekstu posledica pandemija na međunarodnu bezbednost najviše ističu ekonomske posledice. Tako se $u$ istraživanju Dejvida Bluma (David Bloom), Danijela Kadarete (Daniel Cadarette) i Sevilja (JP Sevilla) navodi da očekivani ekonomski gubici od pandemijskog gripa na godišnjem nivou iznose oko 500 milijardi dolara (0,6\% globalnog prihoda) ${ }^{88}$ Ukoliko bi pak svet pogodila pandemija ranga španskog gripa, BDP na globalnom nivou umanjio bi se za oko 5\%, a $60 \%$ tog smanjenja odnosilo bi se na borbu protiv zaraze. ${ }^{89}$ Prema procenama Svetske banke, pandemija virulentnosti španskog gripa koštala bi modernu ekonomiju tri bilona dolara ili 4,8\% BDP, dok bi gubici u slučaju pandemije umerene virulentnosti iznosili oko 2,2\%. Prema ovom modelu gubici za Južnu Aziju iznosili bi 53 milijarde dolara, a za podsaharsku Afriku i do 28

85 "The world health report 2007: a safer future: global public health security in the 21st century", WHO, Geneva, 2007.

${ }^{86}$ Andrew T. Price-Smith, Contagion and Chaos Disease, Ecology, and National Security in the Era of Globalization, op. cit., p. 21.

${ }^{87}$ Filip Ejdus, Međunarodna bezbednost: teorije, sektori $i$ nivoi, JP Službeni glasnik i Beogradski centar za bezbednosnu politiku, Beograd, 2012, str. 261.

${ }^{88}$ David E Bloom, Daniel Cadarette and JP Sevilla, "Epidemics and Econimics", Finance $\mathcal{E}$ Development, op. cit., p. 46.

${ }^{89}$ Victoria Y Fan, Dean T Jamison and Lawrenece H Summers, "Pandemic risk: how large are the expected losses?", Bulletin of the World Health Organization, Vol. 96 No. 2, December 2018, p. 129. 
milijardi dolara. ${ }^{90}$ Iako se navedeni podaci odnose na predikcije pandemija, evidentno je da su zarazne bolesti u skorijoj istoriji imale negativne posledice na ekonomiju, dok se posledice pandemije COVID-19 smatraju katastrofalnim. Tako su procenjeni ekonomski gubici usled SARS-a 2003. godine iznosili 40 milijardi dolara, a prema procenama Azijske razvojne banke ekonomski uticaj SARS-a u Istočnoj Aziji iznosio je 18 milijardi dolara - oko 0,6\% BDP. ${ }^{91}$ Ekonomski gubici usled pandemije H1N1 2009. godine procenjeni su između 45 i 55 milijardi dolara, a troškovi epidemije ebole u periodu između 2014. godine i 2016. godine, 53 milijarde dolara. ${ }^{92}$ Prema podacima Međunarodnog monetarnog fonda, globalna ekonomija zbog

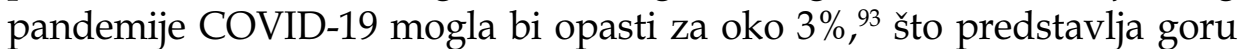
situaciju od svetske ekonomske krize 2008. godine. Projekcije Svetske banke za područje Zapadnog Balkana, pokazuju negativan regionalni rast koji se može kretati od $-3 \%$ do $-5,6 \%$, a smatra se da će stopa rasta u evrozoni u kojoj se nalaze glavni trgovinski partneri za države sa ovog područja usporiti za $1 \% .^{94}$

Gubici su zabeleženi u svim sferama, dok se zbog uvedenih mera avioindustrija našla u najvećoj krizi ikada. Prema izveštaju Međunarodne organizacije za civilno vazduhoplovstvo u odnosu na 2019. godinu broj međunarodnih putnika na početku 2020. godine opao je od $44 \%$ do $80 \%$. Za oporavak se predviđaju dva moguća scenarija: „V- oblik” (V-Shaped) normalan oblik recesije gde nakon kraćeg prekida sledi brzi oporavak $\mathrm{i}$, $\mathrm{U}-$

90 "A World at Risk: annual report on global preparedness for health emergencies", Global Preparedness Monitoring Board, World Health Organization, Geneva, 2019, p. 13.

${ }^{91}$ David L. Heyman, Alison West, "Emerging infections: Threats to health and economic security", in: Simon Rushton and Jeremy Youde (eds), Routledge Handbook of Global Health Security, Routledge, London and New York, 2015, p. 99.

92 "A World at Risk: annual report on global preparedness for health emergencies", op. cit., p. 13.

93 "World Economic Outlook: The Great Lockdown", International Monetary Fund, April 2020. https://www.imf.org/en/Publications/WEO/Issues/2020/04/14/weoapril-2020, 18/05/2020.

94 "The Economic and Social Impact of COVID-19", Western Balkans Regular Economic Report No. 17, World Bank Group, Spring 2020, http:/ / documents.worldbank.org/ curated/en/301261588088338100/pdf/The-Economic-and-Social-Impact-of-COVID19-Setting-the-Stage.pdf, 31/05/2020. 
oblik" (U-Shape) - produženi prekid i slab ekonomski oporavak sa mogućnošću da se ne vrati trend linija rasta „L oblik” (L-shaped) ${ }^{95}$

Podaci Svetske turističke organizacije Ujedinjenih nacija (UNWTO) pokazuju da je $100 \%$ svetskih destinacija uvelo restikcije na putovanja, što je dovelo do gubitaka u turizmu između 910 milijardi i 1,2 biliona dolara, kao i gubitaka između 100 i 120 miliona radnih mesta. ${ }^{96} \mathrm{U}$ zavisnosti od trajanja pandemije i restriktivnih mera, gubici će verovatno biti umnogome veći.

Pandemija je uticala i na pad cene sirove nafte dovodeći do finansijske nestabilnosti pojedinih država, ${ }^{96}$ kao i značajnog potresa na berzi. ${ }^{97}$

Međutim, pandemija COVID-19 nije uticala samo na ekonomiju, već i na druge aspekte međunarodnih odnosa i bezbednosti, dovodeći do "geopolitičkog zemljotresa" ${ }^{\prime 98} \mathrm{i}$,preusmeravanja sveta u novu, opasno nestabilnu, fazu" ${ }^{99}$ Geopolitičko rivalstvo i već narušeni odnosi između SAD i Kine, tokom pandemije postali su još zategnutiji. SAD smatraju da je Kina odgovorna za pandemiju, a u političkom diskursu COVID-19 često nazivaju ,"kineskim virusom" ${ }^{100}$ Kao što je naveo Prajs-Smit, zaraza može

95 "Effects of Novel Coronavirus (Covid-19) on Civil Aviation: Economic Impact Analysis" ICAO, 07 May 2020, https://www.icao.int/sustainability/Documents /COVID-19/ICAO_Coronavirus_Econ_Impact.pdf, 15/05/2020.

${ }^{96}$ Claudiu Tiberiu Albulescu, "Coronavirus and oil price crash", March 2020, https://www.researchgate.net/publication/339946321_Coronavirus_and_oil_price_ crash_A_note, 13/05/2020.

${ }^{97}$ Angela Weiss, "Coronavirus: Stock markets suffer worst quarter since 1987", BBC, 31 March 2020, https://www.bbc.com/news/business-52113841, 20/05/2020.

${ }^{98}$ Javi Lopez, "The coronavirus: A geopolitical earthquake", European Council on Foreign Relations, $2^{\text {nd }}$ April 2020, https://www.ecfr.eu/article/commentary_the_ coronavirus_a_geopolitical_earthquake, 16/05/2020.

${ }^{99}$ Robert Muggah, David Steven, Liv Torres, "We urgently need major cooperation on global security in the COVID-19 era", World Economic Forum, 23 April 2020, https://www.weforum.org/agenda/2020/04/we-need-major-cooperation-onglobal-security-in-the-covid-19-era/, 02/06/2020.

${ }^{100}$ Prema podacima baze Factabse samo u periodu između 16. i 20. marta 2020. godine, predsednik Tramp je koristio izraz "kineski virus” više od 20 puta, Jérôme VialaGaudefroy, Dana Lindaman, "Donald Trump's 'Chinese virus': the politics of naming", 21 April, 2020, https://theconversation.com/donald-trumps-chinesevirus-the-politics-of-naming-136796, 11/08/2020. U jednom od tvitova napisao je: „SAD će snažno podržati one industrije, poput avio i drugih, koje su posebno pogođene kineskim virusom. Bićemo jači nego ikad pre!", https://twitter.com/ realDonaldTrump/status/1239685852093169664, 11/08/2020. 
uticati i na efikasno funkcionisanje međunarodnih organizacija i stvoriti probleme u saradnji između nacionalnih država i drugih subjekata ${ }^{101}$, što se i desilo u slučaju pandemije COVID-19. Naime, SAD su optužile Svetsku zdravstvenu organizaciju da je pod uticajem i kontrolom Kine, a pokušaj glasanja u Savetu bezbednosti UN o rezoluciji o prekidu vatre na globalnom nivou završen je vetom $S A D$, zbog toga što je rezolucija sadržala referencu o Svetskoj zdravstvenoj organizaciji. ${ }^{102} \mathrm{Na}$ kraju, 29. maja 2020. godine, SAD su donele odluku da istupe iz Svetske zdravstvene organizacije. ${ }^{103}$

Pandemija je dovela $u$ pitanje i demokratske vrednosti, poput solidarnosti i saradnje, budući da je nespremnost za pandemiju i nedostatak medicinske opreme doveo svet $u$,globalnu džunglu”, gde države „ratuju u nabavkama/licitaciji" ${ }^{104}$ Oprema predviđena za jednu državu, često je $u$ poslednjem trenutku sa aerodroma preusmeravana ka drugoj državi, koja bi ponudila više novca. ${ }^{105}$ Za ovakve aktivnosti angažovane su diplomate, službe bezbednosti i mnogi drugi subjekti (,,moderni pirati"), ${ }^{106}$ a predsednik SAD pozvao se čak na legislativu iz perioda Korejskog rata (Korean War-era Defense Production Act) kojom se kompanije primoravaju da daju prednost vladi SAD u odnosu na konkurente. ${ }^{107}$ Ujedno, prema podacima Svetske

${ }^{101}$ Price-Smith, Contagion and Chaos Disease, Ecology, and National Security in the Era of Globalization, op. cit.

${ }^{102}$ Kylie Atwood, "US blocks UN resolution on global coronavirus ceasefire after China pushes WHO mention", CNN, 09 May 2020, https:/ / edition.cnn.com/2020/05/09/ politics/us-rejects-un-coronavirus-resolution-china-who/index.html, 21/05/2020.

${ }^{103}$ Jason Hoffman and Maegan Vazquez, "Trump announces end of US relationship with World Health Organization", CNN, 29 May 2020, https:/ / edition.cnn.com/2020 /05/29/politics/donald-trump-world-health-organization/index.html, 30/05/2020.

${ }^{104}$ Clary Estes, "Satates are Being Forced Into Bidding Wars To Get Medical Equipment To Combat Coronavirus", Forbes, 28 March 2020, https:/ / www.forbes.com/ sites/ claryestes/2020/03/28/states-have-are-being-forced-into-bidding-wars-to-getmedical-equipment-to-combat-coronavirus/\#5635bd601cde, 16/05/2020.

105 "EU warns of global bidding war for medical equipment", Financial Times, 07 April 2020, https:/ / www.ft.com/content/a94aa917-f5a0-4980-a51a-28576f09410a, 21/05/2020.

${ }^{106}$ Rade Maroević, "Bitka za masku više, Divlji zapad na tržištu zaštitne opreme”, RTS, 4. april 2020, https://www.rts.rs/page/stories/sr/\%D0\%9A \%D0\%BE \%D1\%80\% D0\%BE\%D0\%BD\%D0\%B0\%D0\%B2\%D0\%B8\%D1\%80\%D1\%83\%D1\%81/story/313 8/koronavirus-u-svetu/3911977/koronavirus-svet-maske-otimacina.html, 14/05/2020.

107 Ana Swanson, Zolan Kanno-Youngs, Maggie Haberman, “Trump Seeks to Block 3M Mask Exports and Grab Masks From Its Overseas Customers", The New York Times, 
carinske organizacije, više od 80 država (među kojima su SAD, Rusija, Velika Britanija, Svajcarska, Turska, Tajland, Indija, Mađarska, Norveška, EU, Evroazijska ekonomska unija, ali i Srbija), usvojile su legislative kojima se privremeno zabranjuje izvoz određene medicinske opreme. ${ }^{108}$

Kina se izuzela iz ove "džungle" svojom, kako je nazvana, "diplomatijom maski", ${ }^{109}$ odnosno pružanjem medicinske pomoći drugim državama. Američke unilateralne odluke, poput zabrane putovanja za EU $\mathrm{s}$ jedne strane, i kineska asertivnost u pružanju pomoći s druge strane, „pokrenula su preispitivanje strateškog pejzaža EU”. ${ }^{110}$ Međutim, prema shvatanju EU, odluka Kine da pošalje medicinsko osoblje i opremu nije samo akt solidarnosti, već $i$ „,vežba iz geopolitike”. Naime, još 2019. godine u dokumentu Evropske komisije (EU-China - A strategic outlook) Kina je označena kao "strateški partner" ali i "sistemski rival”, 111 dok se u istraživanju Francuskog instituta za međunarodne odnose navodi, da su „odnosi sa Kinom usred pandemije podstakli unutrašnji politički razdor u pojedinim državama, istovremeno naglašavajući podele unutar Evrope" ${ }^{112}$ Promene u odnosima osetile su se i u Srbiji. Iako je članstvo u EU definisano

3 April 2020, https://www.nytimes.com/2020/04/03/us/politics/coronavirustrump-3m-masks.html, 21/05/2020.

108 "List of national legislation of countries that adopted temporary export restrictions on certain categories of critical medical supplies in response to COVID-19", World Custom Organization, 2020, http://www.wcoomd.org/en/topics/facilitation/ activities-and-programmes/natural-disaster/list-of-countries-coronavirus.aspx 29/05/2020.

${ }^{109}$ Brian Wong, "China's Mask Diplomacy", The Diplomat. 25 March 2020, https://thediplomat.com/2020/03/chinas-mask-diplomacy/, 15/05/2020.

${ }^{110}$ Mario Esteban, et al. (eds), "Europe in the Face of US-China Rivalry", A Report by the European Think-tank Network on China (ETNC), January 2020, p. 15 http://www.realinstitutoelcano.org/wps/wcm/connect/82e36c36-03a1-40f2-81a09a78ea6dfa95/ETNC-Europe-in-the-face-of-US-China- rivalry.pdf?MOD=AJPERES \&CACHEID=82e36c36-03a1-40f2-81a0-9a78ea6dfa95, 24/05/2020.

111 "Joint Communication to the European Parliament, the European Council and the Council. EU-China - A strategic outlook", European Commission, 2019, https://ec.europa.eu/commission/sites/beta-political/files/communication-euchina-a-strategic-outlook.pdf, 22/05/2020.

112 "Covid-19 and Europe-China Relations A country-level analysis", French Institute of International Relations, European Think-tank Network on China (ETNC) Special Report - 29 April 2020 p. 9, https://www.ifri.org/sites/default/files/atoms/files /etnc_special_report_covid-19_china_europe_2020.pdf, 29/05/2020. 
kao jedan od nacionalnih interesa, pandemija je, prema rečima predsednika Vučića, pokazala da "evropska solidarnost ne postoji”, dok je Kini garantovao „vekovno i čelično prijateljstvo". ${ }^{113}$

Pandemija je uticala i na intezitet oružanih sukoba. Prema istraživanju Ide Tobiasa (Ide Tobias), u tri od devet analiziranih država došlo je do smanjenja inteziteta sukoba, dok je u ostalim državama on pak eskalirao (poput Avganistana), kako zbog slabosti unutar država, tako i zbog smanjene pažnje i mera međunarodne zajednice usled pandemije. ${ }^{14}$ Prema podacima baze podataka Lokacije $i$ događaji u vezi sa oružanim sukobima: COVID-19 - praćenje nereda, nakon izbijanja pandemije došlo je povećanja „mob nasilja”, nasilja koje vrše spontano formirane grupe. Podaci pokazuju da su sukobi između ovih grupa i državnih snaga bezbednosti porasli za $75 \%$ u periodu nakon izbijanja pandemije. ${ }^{115}$

Pored navedenih, posledice pandemije COVID-19 po međunarodnu bezbednost mogle bi se sagledavati i sa drugih aspekata. Tako je direktor Svetskog programa hrane UN upozorio na pandemiju gladi zbog širenja COVID-19, ukazujući na to da bi svet 2020. godine mogla pogoditi najveća humanitarna kriza od Drugog svetskog rata. U svom izlaganju on je izneo podatke da svake noći 821 milion ljudi odlazi gladno na spavanje, a da je 135 miliona ljudi na ivici izgladnjivanja. Ovakva situacija dodatno je pogoršana pandemijom COVID-19, usled velikih ekonomskih gubitaka i preduzetih mera. Tako je, npr. zbog zatvaranja škola, više od 370 miliona dece ostalo bez neophodnih nutritijenata/obroka koje dobijaju u školi. ${ }^{116}$ Pandemija je uticala i na sferu sajber bezbednosti. Prema istraživanju Instituta UN za istraživanje interregionalnog kriminala i pravde (UN Interregional Crime and Justice Research Instuitute) u januaru 2020. godine Gugl

${ }^{113}$ Julija Simić, "Serbia turns to China due to 'lack of EU solidarity' on coronavirus", EURACTIV, 18 May 2020, https:/ / www.euractiv.com/section/china/news/serbiaturns-to-china-due-to-lack-of-eu-solidarity-on-coronavirus/

${ }^{114}$ Ide Tobias, "COVID-19 and Armed Conflict", 17 May 2020, https:/ / papers.ssrn. com/sol3/papers.cfm?abstract_id=3603248, 27/05/2020.

115 "CDT Spotlight: Mob Violence", ACLED, 2020, https:/ /acleddata.com/2020/05/ 21/cdt-spotlight-mob-violence/, 22/05/2020.

116 "WFP Chief warns of hunger pandemic as COVID-19 spreads (Statement to UN Security Council)", World Food Programme, 21 April 2020, https:/ / www.wfp.org/ news/wfp-chief-warns-hunger-pandemic-covid-19-spreads-statement-un-securitycouncil, 30/05/2020. 
(Google) je registrovao 149.000 aktivnih ,"phising" sajtova. U februaru je registrovano duplo više ovakvih sajtova (293.000), dok je u martu taj broj iznosio 522.000 (povećanje za 350\% od januara) (Radoini, 2020). Tokom pandemije zabeležen je i veliki broj sajber napada, a meta je, između ostalih, bila i Svetska zdravstvena organizacija. Više od 450 aktivnih imejl adresa i šifri je "procurilo"', a potom su isti korišćeni za prevare u cilju preusmeravanja donacija namenjenih za Fond solidarnosti u odgovoru na COVID-19 (COVID-19 Solidarity Response Fund). ${ }^{117}$ Ujedno, pandemija je podstakla širenje dezinformacija i lažnih vesti, straha, ksenofobije i mržnje, najviše putem društvenih mreža, $u$ toj meri da je uporedo sa borbom protiv pandemije proglašena i borba protiv infodemije. Analiza komunikacije putem društvenih mreža, pokazala je da je debata o uzroku i/ili poreklu virusa bila rasno obojena i ksenofobična (uglavnom se koristio haštag \#KungFlu ili \#ChinaVirus), da su dominirale teorije zavere (povezivanje 5G tehnologije sa pandemijom, prikazivanje Gejtsa (Gates) kao tvorca virusa, kontrola populacije, čipovanje, novi svetski poredak), a širile su se i dezinformacije o lekovima u kućnim uslovima koji su u pojedinim slučajevima ozbiljno ugrozili zdravlje i živote ljudi (konzumacija čistog alkohola, kolidnog srebra, hemijskih sredstava i sl). ${ }^{118}$

Ovim se ne iscrpljuju aspekti bezbednosti na koje pandemija COVID19 ima uticaja. Možemo govoriti i uticaju COVID-19 na organizovani kriminal, terorizam, korupciju i transparentnost u nabavkama medicinske opreme, migrantsku krizu, nasilje nad ženama, kao i mnogim drugim. Međutim, sagledavanje svih aspekata odnosa pandemije i bezbednosti umnogome prevazilazi okvire ovog rada.

\section{Zaključak}

Tokom perioda od petnaest vekova pandemije zaraznih bolesti značajno su uticale na tok istorije čovečanstva. Zaraze su uticale na demografiju,

117 "WHO reports fivefold increase in cyber attacks, urges vigilance", WHO, 23 April 2020, https:/ / www.who.int/ news-room/detail/23-04-2020-who-reports-fivefoldincrease-in-cyber-attacks-urges-vigilance

${ }^{118}$ Melanie Smith, Erin McAweeney, Lea Ronzaud, “The Covid-19 'Infodemic'. A Preliminary Analysis of the Online Conversation Surrounding the Coronavirus Pandemic", 21 April 2020, https:/ / graphika.com/reports/the-covid-19-infodemic/, 30/05/2020. 
ekonomiju, balans moći u međunarodnim odnosima i dovodile u pitanje opstanak pojedinih država i sistema društvenog uređenja. Tako su se pored velike stope mortaliteta, posledice pandemija kuge $u$ VI i XIV veku manifestovale i promenama regionalnog balansa moći, razvoja ksenofobije, slabljenja i nestanka Vizantijskog carstva, osvajanja Mamelučkog carstva i raspada feudalnog sistema. Uvođenje prvih zdravstvenih mera i nastanak karantina u XIV veku uslovio je diskriminaciju manjinskih grupa i stigmatizaciju obolelih, što je postalo obeležje svih budućih epidemija i pandemija. Velike posledice u svim sferama ostavila je i pandemija španskog gripa 1918. godine, koja je uticala i na sam tok Prvog svetskog rata, a mere koje su države preduzimale u cilju sprečavanja zaraze preispitivane su u tadašnjim medijima, što je doprinosilo širenju panike. I pored svega navedenog, razmatranje zaraznih bolesti sa stanovišta bezbednosti započinje tek krajem 90-ih godina XX veka, kada se pažnja sa tradicionalnih (vojnih) pretnji bezbednosti pomera na netradicionalne pretnje bezbednosti. Od tog perioda, a naročito od usvajanja Rezolucije 1308, zdravlje počinje da se posmatra kroz prizmu bezbednosti. Međutim, ne smatra se svaki patogen pretnjom bezbednosti, već to zavisi od nekoliko kriterijuma, od kojih u savremenom društvu dominira onaj ekonomski. Tako su procenjeni ekonomski gubici usled SARS-a 2003. godine iznosili 40 milijardi dolara, pandemije H1N1 2009. godine između 45 i 55 milijardi dolara, a epidemije ebole u periodu između 2014. godine i 2016. godine, 53 milijarde dolara. Sve ove zaraze povlačile su za sobom i niz restriktivnih mera koje su države preduzimale u cilju kontrole i sprečavanja širenja zaraze. Ovakve mere često su se kosile sa ljudskim i manjinskim pravima, doprinosile diskriminaciji i stigmatizaciji, što je neretko rezultiralo protestima i nemirima. Stoga pojedini autori smatraju, da upravo istorijska perspektiva pojava zaraznih bolesti i uvođenja restriktivnih mera može da nam posluži za razumevanje i pravovremeno reagovanje na neke nove pandemije. Ali pandemija COVID-19 2020. godine, pokazala je da lekcije ipak nisu naučene. Mnoge nepoznanice $u$ vezi sa virulentosti, širenjem i posledicama novog virusa, izazvale su globalni strah među ljudima, a države su preduzele niz restriktivnih mera. Pandemija je ugrozila svetsku ekonomiju, prizemljila avione, zatvorila svetske turističke destinacije, dovela do pada cene nafte i kraha finansijskog tržišta. Pandemija je izazvala potrese na području geopolitike i međunarodnih odnosa i dovela u pitanje demokratske vrednosti, poput solidarnosti i saradnje, budući da je nespremnost za pandemiju i nedostatak medicinske opreme prinudio 
države da „,ratuju u nabavkama/licitaciji”. Ujedno, mnoge države usvojile su legislative kojima se privremeno zabranjuje izvoz određene medicinske opreme. Zatvaranje granica, uvođenje karantina i izolacije, ugrožavanja ljudskih i manjinskih prava, u mnogim državama podstaklo je antivladine demonstracije. Diskriminacija i stigmatizacija postala je globalni fenomen, a zbog širenja ksenofobije, dezinformacija i straha putem novih medija, proglašena je i borba protiv infodemije. Iako radom nisu obuhvaćene sve pandemije i njihov uticaj na bezbednost, niti su predstavljene sve posledice pandemije COVID-19, ipak se iz onog što je prikazano može zaključiti da lekcije iz prošlosti nisu savladane, da savremeni svet nije spreman na pojavu novih pandemija jer, između ostalog, kada su u pitanju zarazne bolesti imamo kratkotrajno kolektivno pamćenje. Imajući u vidu predikcije da bi u savremenom svetu u slučaju pojave zaraze slične virulentnosti kao španski grip za manje od 36 sati umrlo od 50 do 80 miliona ljudi; da bi ovakva zaraza izazvala opštu paniku, destabilizovala nacionalnu bezbednost, ozbiljno ugrozila globalnu ekonomiju i međunarodnu bezbednost, zbog toga mnogo više pažnje mora da se posveti izučavanju događaja iz prošlosti i primeni naučenih lekcija.

\section{Bibliografija}

A World at Risk: annual report on global preparedness for health emergencies, Global Preparedness Monitoring Board, World Health Organization, Geneva, 2019.

Bjørkdahl, Kristian, Carlsen, Benedicte (eds), Pandemics, Publics, and Politics. Palgrave, Singapore, 2019.

Bloom, E. David, Cadarette, Daniel and Sevilla, J.P., „Epidemics and Econimics", Finance E Development, Vol.55, No. 2, June, 2018, pp. 46-49.

Carter, A. Colin, Huie, Jascqueline, "Market Effects of Searching for Mad Cows", Giannini Foundation of Agriculture and Economics, Vol. 8, No. 2, Sep/Oct 2004, pp. 4-7.

Diamond, M. Jared, Guns, Germs, and Steel: The Fates of Human Societies, WW Norton \& Company, New York, 1999.

Dimitrijević, Ivan, Paraušić, Ana, Katalog baza podataka za istraživanja u oblasti bezbednosti, Fakultet bezbednosti, Beograd, 2017. 
Dixon, Simon, McDonald, Scott and Roberts, Jennifer, "The Impact of HIV and AIDS on Africa's Economy", BMJ, Vol. 324, January 2002, p. 233.

Elbe, Stefan, "HIV/AIDS and the Changing Landscape of War in Africa." Quarterly Journal: International Security, Vol. 27, No. 2., Fall 2002, pp. 159-177.

Ejdus, Filip, Međunarodna bezbednost: teorije, sektori i nivoi, JP Službeni glasnik i Beogradski centar za bezbednosnu politiku, Beograd, 2012.

Enmark, Christ, Disease and Security. Natural plagues and biological weapons in East Asia, The Routledge, New York \& London, 2007.

Fan, Y. Victoria, Jamison, T. Dean and Summers, H. Lawrence, "Pandemic risk: how large are the expected losses?", Bulletin of the World Health Organization, Vol. 96 No. 2, December 2018, pp. 129-134.

Fidler, P. David, "Health as Foreign Policy: Between Principle and Power". Whitehead Journal of Diplomacy and International Relations, Vol. 6, No. 2, 2005, pp. 179-194.

Hays, N. Jo, Epidemics and Pandemics. Their Impacts on Human History, ABCCLIO, Inc., Santa Barbara, 2005.

Hays, N. Jo, The Burdens of Disease Epidemics and Human Response in Western History, Rutgers University Press, New Brunswick, New Jersey and London, 2009.

Heyman, L. David, West, Alison, "Emerging infections: Threats to health and economic security", in: Rushton, Simon and Youde, Jeremy (eds), Routledge Handbook of Global Health Security, Routledge, London and New York, 2015, pp. 92-105.

Huang, Yanzhong, "Pandemics and security", in: Rushton, Simon and Youde, Jeremy (eds), Routledge Handbook of Global Health Security, Routledge, London and New York, 2015, pp. 83-92.

Huremović, Damir, "Brief History of Pandemics (Pandemics Throughout History)", Psychiatry of Pandemics: A Mental Health Response to Infection Outbreak 7-35, 16 May 2019, doi:10.1007/978-3-030-15346-5_2.

Makins, Kolin, "Zdravlje”, u: Vilijams, Pol (ur), Uvod u studije bezbednosti, Fakultet bezbednosti i JP Službeni glasnik, Beograd, 2012, str. 358-377.

Mackowiak, A. Philip, Sehdev, S. Paul, "The Origin of Quarantine", Clinical Infectious Diseases, Vol. 35, No. 91, November 2002, pp. 1071-1072.

Moor, W. Jason, "THE CRISIS OF FEUDALISM: An Environmental History", Organization E Environment, Vol. 15, No. 3, September 2002, pp. 301-322. 
O'Manique, Collen and Fouire, Piter, "Security and health in the twentyfirst century", in: Cavelty, Dunn Myriam and Mauer, Victor (eds), Routledge Handbook of Security Studies, Routledge, London and Ney York, 2010, p. 243.

Pirages, Dennis and Runci, Paul, "Ecological Interdependence and the Spread of Infectious Disease", in Cusimano Maryann (Ed), Beyond Sovereignty: Issues for a Global Agenda, New York, St. Martin's Press, 2000, pp. 173-194.

Pirages, Dennis, "Microsecurity: Disease organisms and human wellbeing", Washington Quarterly Vol. 18, Issue 4, 1995, pp. 5-12.

Price-Smith, T. Andrew, Contagion and Chaos Disease, Ecology, and National Security in the Era of Globalization, The MIT Press, Cambridge, Massachusetts London, 2009.

Price-Smith, T. Andrew, The Health of Nations. Infectious Disease, Environmental Change, and Their Effects on National Security and Development, The MIT Press, Cambridge, Massachusetts London, 2002.

"Resolution 1308 (2000)", Security Council of the United Nations, 17 July 2000.

Rokvic, Vanja, Jeftic, Zoran, Ajzenhamer, Vladimir, " Public health in Serbia through the lens of security", IJPH, Vol. 4, No. 9, September 2016, pp. 1136-1145.

Rosenau, N. James, Along the domestic-foreign Frontier. Exploring governance in a turbulent world, Cambridge University Press, New York, 1997.

"The world health report 2007: a safer future: global public health security in the 21st century", WHO, Geneva, 2007.

Tognotti, Eugenia, "Lessons from the history of quarantine, from plague to influenza A", Emerging Infectious Diseases, Vol. 19, No. 2, February 2013, p. 257.

\section{Internet izvori}

Albulescu, Tiberiu Claudiu, "Coronavirus and oil price crash”, March 2020, https://www.researchgate.net/publication/339946321_Coronavirus_a nd_oil_price_crash_A_note, 13/05/2020.

Atwood, Kylie, "US blocks UN resolution on global coronavirus ceasefire after China pushes WHO mention", CNN, 09 May 2020, https:/ / edition. 
cnn.com/2020/05/09/politics/us-rejects-un-coronavirus-resolutionchina-who/index.html, 21/05/2020.

Burke, Adam, "Peace and the pandemic: the impact of COVID-19 on conflict in Asia", Devpolicy Blog, 14 April 2020, https://devpolicy.org/peaceand-the-pandemic-the-impact-of-covid-19-on-conflict-in-asia20200414/, 26/05/2020.

"CDT Spotlight: Mob Violence", ACLED, 2020, https://acleddata.com/ 2020/05/21/cdt-spotlight-mob-violence/, 22/05/2020.

"Covid-19 and Europe-China Relations A country-level analysis", French Institute of International Relations, European Think-tank Network on China (ETNC) Special Report - 29 April 2020, https://www.ifri.org/ sites/default/files/atoms/files/etnc_special_report_covid19_china_europe_2020.pdf, 29/05/2020.

"COVID-19-related discrimination and stigma: a global phenomenon?", UNESCO, 25 May 2020, https://en.unesco.org/news/covid-19-relateddiscrimination-and-stigma-global-phenomenon, 29/05/2020.

"Covid-19 Disease Response“, Situation Report 17, IOM, 23-29 May 2020, https:/ / reliefweb.int/sites/reliefweb.int/files/resources/iom_covid19_sitrep17_23-29may2020_final.pdf, 31/05/2020.

Delivorias, Angelos, Scholz, Nicole, "Economic impact of epidemics and pandemics", European Parliamentary Research, February 2020, https://www.europarl.europa.eu/RegData/etudes/BRIE/2020/64619 5/EPRS_BRI(2020)646195_EN.pdf, 23/05/2020.

Dettmer, Jamie, „Hungary: The First Dictatorship in the EU?”, VOA News, 06 May 2020, https://www.voanews.com/covid-19-pandemic/ hungary-first-dictatorship-eu, 12/05/2020.

Dundorf, Daniel, et al, „,Coronavirus: The world in lockdown in maps and charts", BBC News, 7 April 2020, https://www.bbc.com/news/world52103747, 15/05/2020.

Durr, Eric, "Worldwide flu outbreak killed 45,000 American Soldiers during World War I", 31 August 2018, U.S Army, https://www.army.mil/ article/210420/worldwide_flu_outbreak_killed_45000_american_soldie rs_during_world_war_i 10/05/2020.

Donmez, Binnur Beyza, "Report says virus fuels anti-Asian racism, xenophobia Governments should take urgent steps to counter intolerance, says Human Rights Watch amid coronavirus pandemic", 
Andaolu Agency, 13 May 2020, https://www.aa.com.tr/en/latest-oncoronavirus-outbreak/ report-says-virus-fuels-anti-asian-racismxenophobia/1839509, 30/05/2020.

"Economic Impact and International Trade", BSE Inquiry Report, Vol. 10, 1996, http://www.fao.org/livestock/AGAP/FRG/Feedsafety/PDFs /philips10.pdf, 15/04/2020.

"Effects of Novel Coronavirus (Covid-19) on Civil Aviation: Economic Impact Analysis" ICAO, 07 May 2020, https://www.icao.int/ sustainability/Documents / COVID-19/ICAO\%20Coronavirus\% 202020\%2005\%2007\%20Economic\%20Impact.pdf, 15/05/2020.

Estes, Clary, "Satates are Being Forced Into Bidding Wars To Get Medical Equipment To Combat Coronavirus", Forbes, 28 March 2020, https://www.forbes.com/sites/claryestes/2020/03/28/states-haveare-being-forced-into-bidding-wars-to-get-medical-equipment-tocombat-coronavirus/\#5635bd601cde, 16/05/2020.

Esteban, Mario, et al. (eds), "Europe in the Face of US-China Rivalry", A Report by the European Think-tank Network on China (ETNC), January 2020, http://www.realinstitutoelcano.org/wps/wcm/connect/82e 36c36-03a1-40f2-81a0-9a78ea6dfa95/ETNC-Europe-in-the-face-of-USChina-rivalry.pdf?MOD=AJPERES\&CACHEID=82e36c36-03a1-40f281a0-9a78ea6dfa95, 24/05/2020.

"EU warns of global bidding war for medical equipment", Financial Times, 07 April 2020, https://www.ft.com/content/a94aa917-f5a0-4980-a51a28576f09410a, 21/05/2020.

“European Court Of Human Rights Has Initiated Procedure Against Serbia For Lack Of Support For The Most Vulnerable In The Fight Against Coronavirus", Forum Roma Srbije, 2020, http://www.frs.org.rs/en/ european-court-of-human-rights-has-initiated-procedure-againstserbia-for-lack-of-support-for-the-most-vulnerable-in-the-fight-againstcoronavirus/, 27/05/2020.

Hoffman, Jason and Vazquez, Maegan, "Trump announces end of US relationship with World Health Organization", CNN, 29 May 2020, https:/ / edition.cnn.com/2020/05/29/politics/donald-trump-worldhealth-organization/index.html, 30/05/2020.

„HIV/AIDS Global Trends and Data“, WHO, https://www.who.int/ gho/hiv/en/; 14/05/2020. 
"International Tourism and Covid-19", UNWTO, 2020, https://www. unwto.org/international-tourism-and-covid-19, 22/05/2020.

"Increased Demonstration Activity Over Government Response“ , ACLED: COVID-19 Disorder Tracker, 2020, https://acleddata.com/analysis/ covid-19-disorder-tracker/\#1585775314361-2ee40e97-5aec, 28/05/2020.

"Joint Communication to the European Parliament, the European Council and the Council. EU-China - A strategic outlook", European Commission, 2019, https://ec.europa.eu/commission/sites/betapolitical/files/communication-eu-china-a-strategic-outlook.pdf, 22/05/2020.

Lenzi, Saverio, Di Filippo Andrea, Bordell Vega Javier, "The economy and coronavirus: Weekly Picks", European Parliament, 06 April 2020, https://www.europarl.europa.eu/RegData/etudes/BRIE/2020/64571 7/IPOL_BRI\%282020\%29645717_EN.pdf, 23/05/2020.

"List of national legislation of countries that adopted temporary export restrictions on certain categories of critical medical supplies in response to COVID-19", World Custom Organization, 2020, http://www. wcoomd.org/en/topics/facilitation/activities-and-programmes/ natural-disaster/list-of-countries-coronavirus.aspx, 25/05/2020.

Lopez, Javi, "The coronavirus: A geopolitical earthquake", European Council on Foreign Relations, $2^{\text {nd }}$ April 2020. https://www.ecfr.eu/ article/commentary_the_coronavirus_a_geopolitical_earthquake, 26/05/2020.

Maroević, Rade, "Bitka za masku više, Divlji zapad na tržištu zaštitne opreme", RTS, 04. April 2020, https://www.rts.rs/page/stories/ sr $/ \%$ D0\%9A $\%$ D0\%BE\%D1\%80\%D0\%BE\%D0\%BD\%D0\%B0\%D0\%B2\% D0\% B8\% D1\% 80\% D1\% 83\%D1\%81/story/3138/koronavirus-usvetu/3911977/koronavirus-svet-maske-otimacina.html, 14/05/2020.

Muggah, Robert, Steven, David, Torres, Liv, "We urgently need major cooperation on global security in the COVID-19 era", World Economic Forum, 23 April 2020, https://www.weforum.org/agenda/2020/04/ we-need-major-cooperation-on-global-security-in-the-covid-19-era/, 02/06/2020.

Radoini, Adil, "Cyber-crime during the COVID-19 Pandemic", The United Nations Interregional Crime and Justice Research Institute, 11 May 2020, http://www.unicri.it/news/article/covid19_cyber_crime, 30/05/2020. 
"Recession Looms for Western Balkans as Countries Respond to COVID19", Press Release No: 2020/ECA/91, The World Bank, 29 April 2020. https:/ / www.worldbank.org/en/news/press-release/2020/04/29/ recession-looms-for-western-balkans-as-countries-respond-to-covid-19, 30/05/2020.

“Rising State Represion”, ACLED: COVID-19 Disorder Tracker, 2020. https:/ / acleddata.com/analysis/covid-19-disorder-tracker/\#158577 5314361-2ee40e97-5aec, 24/05/2020.

"Secretary-General Denounces 'Tsunami' of Xenophobia Unleashed amid COVID-19, Calling for All-Out Effort against Hate Speech", United Nations, Meetings Coverage and Press Releases, 08 May 2020, https:// www.un.org/press/en/2020/sgsm20076.doc.htm, 27/05/2020.

Simić, Julija, "Serbia turns to China due to 'lack of EU solidarity' on coronavirus", EURACTIV, 18 May 2020, https://www.euractiv.com/ section/china/news/serbia-turns-to-china-due-to-lack-of-eu-solidarityon-coronavirus/, 25/05/2020.

Smith, Melanie, McAweeney, Erin, Ronzaud ,Lea, “The Covid-19 "Infodemic". A Preliminary Analysis of the Online Conversation Surrounding the Coronavirus Pandemic", 21 April 2020, https://graphika.com/reports/the-covid-19-infodemic/, 30/05/2020.

Swanson, Ana, Kanno-Youngs, Zolan and Haberman, Maggi, "Trump Seeks to Block 3M Mask Exports and Grab Masks From Its Overseas Customers", The New York Times. 3 April 2020, https://www.ny times.com/2020/04/03/us/politics/coronavirus-trump-3mmasks.html, 21/05/2020.

"The Covid-19 Crisis in Serbia", OECD, 25 May 2020, https:/ / www.oecd. org/south-east-europe/COVID-19-Crisis-in-Serbia.pdf, 30/05/2020.

"The Economic and Social Impact of COVID-19", Western Balkans Regular Economic Report No. 17, World Bank Group, Spring 2020, http:// documents.worldbank.org/curated/en/301261588088338100/pdf/TheEconomic-and-Social-Impact-of-COVID-19-Setting-the-Stage.pdf, $31 / 05 / 2020$.

"The Global Infectious Disease Threat and Its Implications for the United States", The U.S. National Intelligence Council, 2000, https:/ / www.dni. gov/files/documents/infectiousdiseases_2000.pdf, 19/05/2020. 
Tobias, Ide, "COVID-19 and Armed Conflict", 17 May 2020, https:/ / papers. ssrn.com/sol3/papers.cfm?abstract_id=3603248, 27/05/2020.

"Up to 650000 people die of respiratory diseases linked to seasonal flu each year", WHO, 14 December 2017, https://www.who.int/newsroom/detail/14-12-2017-up-to-650-000-people-die-of-respiratorydiseases-linked-to-seasonal-flu-each-year, 17/05/2020.

Viala-Gaudefroy , Jérôme, Lindaman , Dana, “Donald Trump's 'Chinese virus': the politics of naming", 21 April, 2020, https://the conversation.com/donald-trumps-chinese-virus-the-politics-of-naming136796, 11/08/2020.

Weiss, Angela, "Coronavirus: Stock markets suffer worst quarter since 1987", BBC, 31 March 2020, https://www.bbc.com/news/business52113841, 20/05/2020.

Wong, Brian, "China's Mask Diplomacy", The Diplomat. 25 March 2020, https://thediplomat.com/2020/03/chinas-mask-diplomacy/, 15/05/2020.

"WFP Chief warns of hunger pandemic as COVID-19 spreads (Statement to UN Security Council)", World Food Programme, 21 April 2020, https://www.wfp.org/news/wfp-chief-warns-hunger-pandemiccovid-19-spreads-statement-un-security-council, 30/05/2020.

"WHO reports fivefold increase in cyber attacks, urges vigilance", WHO, 23 April 2020, https://www.who.int/news-room/detail/23-04-2020who-reports-fivefold-increase-in-cyber-attacks-urges-vigilance, 31/05/2020.

"World Economic Outlook: The Great Lockdown", International Monetary Fund, April 2020, https://www.imf.org/en/Publications/WEO/ Issues/2020/04/14/weo-april-2020, 18/05/2020.

"World Tourism Barometer: Special Focus on the Impact of Covid-19", UNWTOWorld Tourism Barometer May 2020, May 2020. https:// webunwto.s3.eu-west-1.amazonaws.com/s3fs-public/202005/Barometer_May2020_full.pdf, 26/05/2020.

"2014-2015 West Africa Ebola Crisis: Impact Update", World Bank Group, 10 May 2016, http://pubdocs.worldbank.org/en/297531463677588 074/Ebola-Economic-Impact-and-Lessons-Paper-short-version.pdf, 22/05/2020. 


\section{Vanja ROKVIĆ}

\section{SECURITY IN AN ERA OF PANDEMICS}

Abstract: The period from the outbreak of the first pandemic, the plague pandemic in the 6th century, to the Covid-19 pandemic in the 21st century, abounded in numerous infectious disease outbreaks that had a significant impact on the state and society and the international community as a whole. In addition to high morbidity and mortality rates, infectious diseases through history have had profound effects on the economy, state governance, security forces, armed conflicts, and the balance of power in international relations. Original and peer-reviewed academic articles, reports of official institutions, and media articles have been drawn to prepare this review article. Also, the relevant databases such as the ACLED - Armed Conflict Location and Event Data Project: COVID-19 Disorder Tracker and International Organization for Migration Displacement Tracking Matrix have been used to summarize and discuss the current state of knowledge about the impact and the consequences of pandemics on both national and international security, with special reference to the Covid-19 pandemic. In this paper, the author concludes that, although throughout human history pandemics have left numerous health effects, the impact on the economy, state governance, the balance of power in international relations, the unpreparedness and global chaos that followed the Covid-19 pandemic have revealed that modern society is afflicted by short collective memory in terms of infectious diseases and their relationship to security.

Keywords: pandemic, national security, international security, Covid-19. 